\title{
Comment on 'The geometry and stratigraphic position of the Maassluis Formation (western Netherlands and south-eastern North Sea)' by Jansen et al. (2004b)
}

\section{F.P. Wesselingh ${ }^{1}$, T. Meijer $^{1}$ \& P. Cleveringa ${ }^{2}$}

1 Naturalis, P.0. Box 9517, 2300 RA, Leiden, The Netherlands. Email: wesselingh@naturalis.nl (corresponding author)

2 Clarissenhof 15, 1115 CA, Duivendrecht, The Netherlands

Manuscript received: December 2004; accepted: February 2005

Two papers (Jansen et al., 2004a, b) in the Netherlands Journal of Geosciences deal with the age and geometry of the Maassluis Formation of the Netherlands. Age estimates are derived mainly from strontium (Sr) isotope measurements (Jansen et al., 2004a). Based on a combination of methods, but most heavily relying on Sr data and sequence boundaries ages based on the Haq curve, the authors (in Jansen et al., $2004 \mathrm{~b}$ ) discuss the possible occurrence of hiatuses in the Maassluis Formation covering intervals of 0.04 to $0.18 \mathrm{Ma}$.

In the first paper, three borehole sections in the Maassluis Formation were measured, Noordwijk, Zegveld and Terschelling. The Terschelling borehole provided inconsistent Sr ages with differences up to 2.5 million years from expected ages for the Maassluis Formation (ca. 1.7 - 2.55 Ma range: see below). The Zegveld borehole in general provided ages between 1.7 and $1.9 \mathrm{Ma}$, but here again very inconsistent measurements (e.g. a 1.25 Ma estimate for the lowest sample) did occur. The oldest age cited for the Maassluis Formation in borehole Noordwijk is 4.70 Ma, some 2.15 Ma older than paleontological evidence suggests.

We are not in agreement with the age indications of Jansen et al. (2004a), based on faunal evidence. Furthermore, the authors use the Haq curve in order to discuss more detailed correlation problems within the Maassluis Formation, where clear evidence exists for pronounced glacioeustacy in the Maassluis Formation, rendering very detailed discussions on age intervals (in Jansen et al., 2004b) obsolete.

In the southern North Sea Basin arctic marine mollusc taxa such as Portlandia arctica, Yoldia lanceolata and Clinocardium ciliatum first appear at the basis of the Maassluis Formation and frequently occur in certain higher levels of the Maassluis Formation (Spaink, 1975). These taxa occur in shallow, as well as in deep water facies. One could argue that the deep water facies is generally older than the shallow water facies, given the general trend of basin infill in the southern North Sea Basin around the Pliocene-Pleistocene transition (Kuhlmann, 2004). Although this may be true, the age cannot be older than Praetiglian (ca. 2.55 Ma: Janssen et al, 2004a) because these taxa are absent in Late Pliocene (Reuverian-C) deep (as well as shallow) water assemblages. Instead, cold (deep) water assemblages of this older age interval show the presence of other (extinct) taxa, such as Carinastarte trigonata (Spaink, 1975). This implies an upper age limit of $2.55 \mathrm{Ma}$ for the base of the Maassluis Formation.

Pliocene (Piacenzian/Reuverian) freshwater mollusc faunas are well known from the Niederrhein area (Schlickum \& Strauch, 1979). These faunas are entirely different from the freshwater taxa that are not uncommonly washed into marine intervals in the Maassluis Formation (Kuijper, 1973). For example, Viviparus glacialis, an important non-marine Praetiglian and Tiglian (Gelasian) indicator (Meijer, 1986), is not known from older deposits, but has been found in the entire stratigraphic interval covered by the Maassluis Formation. This contradicts suggested ages of older then 2.55 Ma for the Maassluis Formation as indicated by Jansen et al. (2004a).

Like the molluscs, the microvertebrates provide independant estimates for the age of the Maassluis Formation. From the vole genus Mimomys the following species have been found in the Maassluis Formation from a large number of sites: $M$. pliocaenicus, M. reidi, M. blanci, M. pitymyoides, and $M$. hordijki (Van Kolfschoten, 1989; Van Kolfschoten \& Van der Meulen, 1986; Van Kolfschoten, \& Tesakov, 1998). Their European record is extensive, well-dated and well-documented and point to mammal zone MN17. Mimomys pliocaenicus and $M$. reidi have their first appearance at the lower boundary of this zone, which has a calibrated age of 2.5 Ma (Agusti et al., 2001). 
The data of the molluscs and the microvertebrates are in strong contrast with age estimates for the Maassluis Formation using $\mathrm{Sr}$ isotope ratios ranging from $-0.71 \mathrm{Ma}$ to $4.70 \mathrm{Ma}$ by Janssen et al. (2004a). The authors (Jansen et al., 2004a) discuss the problematic age estimates of the Sr isotope datings, and attribute them to input of riverine waters or to local groundwater contamination. Riverine input as an explanation for abberant $\mathrm{Sr}$ values seems inconsistent. Molluscan faunas from which the Sr data were obtained are typically fullmarine. Arctica islandica, the species used in most analyses is such a species: it thrives in salinities between 32 and 34 psu. Minimum salinity tolerances are around 22 psu (Cargnelli et al., 1999). The difference in Sr abundance in North Sea waters and Rhine river waters indicates that strong depression of the $\mathrm{Sr}$ signal by river input only takes places under oligohaline salinity conditions (see e.g. Vonhof et al., 1998 for models). Species, such as Arctica islandica, cannot cope with salinity regimes below $5 \mathrm{psu}$. It is more likely that diagenesis (groundwater contamination) caused these problematic age estimates. Diagenesis is indeed common in North Sea Basin Pliocene and Quaternary marine mollusc faunas (see e.g. Johnson et al., 2000).

With two such erroneous $\mathrm{Sr}$ age estimates, the boreholes Terschelling and Zegveld, one should question the reliability of the $\mathrm{Sr}$ derived age estimates from the third section, borehole Noordwijk, without additional age data. Any Sr measurements from North Sea Basin material should at least be accompanied by trace element abundance data, that often yield clear indications of diagenesis (Vonhof et al., 1998).

Many indications about the presence of well-delimited glacial-interglacial cycles in the Maassluis Formation have been found lately. These include occurrences in the northern area of the Dutch continental platform (Kuhlmann, 2004), the very same borehole Noordwijk (Meijer et al., in press) and unpublished data on boreholes covering the SW Netherlands delta-area that are still in study by the first two authors of this comment. With strong glacioeustacy appearing from ca $2.55 \mathrm{Ma}$ ago we fail to see the application of the Haq curve for age estimates in the Maassluis Formation can make much sense.

As a conclusion we consider the molluscan and vertebrate record of the Maassluis Formation as very hard evidence for a Tiglian-Praetiglian age, that constrains the age of the formation to the interval of ca $1.7-2.55 \mathrm{Ma}$.

This comment has greatly benefited from discussions with Hubert Vonhof (VUA). We thank Kees Kasse (VUA) for additional suggestions.

\section{References}

Agusti, J., Cabrera, L., Garces, M., Krijgsman, W., Oms, O. \& Pares, J.M., 2001. A calibrated mammal scale for the Neogene of Western Europe. State of the art. Earth Science Reviews 52: 247-260.
Cargnelli, L.M., Griesbach, S.J., Packer, D.B. \& Weissberger, E., 1999. Essential fish habitat source document: Ocean quahog, Arctica islandica, life history and habitat characteristics. NOAA Technical Memorandum, NMFS-NE-148, $12 \mathrm{pp}$.

Jansen, H.S.M., Huizer, J., Dijkmans, J.W.A. \& Van Hinte, J.E., 2004 a. Strontium (87Sr/86Sr) dating of marine shells from Pliocene and Pleistocene shallow marine deposits in the Netherlands. Netherlands Journal of Geosciences / Geologie en Mijnbouw 83: 41-48.

Jansen, H.S.M., Huizer, J., Dijkmans, J.W.A., Mesdag, C. \& Van Hinte, J.E., 2004b. The Geometry and stratigraphic position of the Maassluis Formation (western Netherlands and southeastern North Sea). Netherlands Journal of Geosciences / Geologie en Mijnbouw 83: 93-100.

Johnson, A.L.A., Hickson, J.A., Swan, J., Brown, M.R., Heaton, T.H.E., Chenery, S. \& Balson, P.S., 2000. The Queen Scallop Aquipecten opercularis: a new source of information on late Cenozoic marine environments in Europe. Geological Society Special Publications 177: 425-439.

Kuhlmann, G., 2004. High resolution stratigraphy and palaeoenvironmental changes in the southern North Sea during the Neogene. Geologica Ultraectina 245: 1-205.

Kuijper, W.J., 1973. Kwartaire land- en zoetwatermollusken uit een boring bij Brielle, Nederland [Quaternary land- and fresh-water molluscs from a borehole near Brielle, The Netherlands]. Mededelingen Werkgroep voor Tertiaire en Kwartaire Geologie 10: 111-137.

Meijer, T., 1986. Non-marine Mollusc biozonation of Quaternary deposits in the Netherlands. Proceedings of the Eighth International Malacological Congress (Budapest, Hungary, 1983): 161-163.

Meijer, T., Cleveringa, P., Munsterman, D.K. \& Verreussel, R.M.C.H., 2005. The Early Pleistocene Praetiglian and Ludhamian pollen stages in the North Sea Basin and their relationship to the marine isotope record. Journal of Quaternary Science (in press).

Schlickum, W.R. \& Strauch, F., 1979. Die Land- und Süsswassermollusken der pliozänen Deckschichten der rheinischen Braunkohle. Abhandlungen der senckenbergischen naturforschenden Gesellschaft 536: 1-144.

Spaink, G., 1975. Zonering van het mariene Onder-Pleistoceen en Plioceen op grond van mollusken fauna's. In: Zagwijn, W.H. \& Van Staalduinen, C.J. (eds): Toelichtingen bij geologische overzichtskaarten van Nederland. Rijks Geologische Dienst, Haarlem: 118-122.

Van Kolfschoten, T., 1989. Zoogdierfossielen uit boringen gelegen op Nederlands grondgebied en in de Noordzee m.u.v. boringen gelegen in het gebied van de kaartbladen 37, 38, 44, 45, 49, 50 en 51. Rapport opgesteld i.o.v. Rijks Geologische Dienst, Haarlem: 116 pp.

Van Kolfschoten, T. \& van der Meulen, A., 1986. Villanyian and Biharian mammal faunas from the Netherlands. Memorie della Società Geologica Italiana 31: 191-200.

Van Kolfschoten, T. \& Tesakov, A.S., 1998. The late Pliocene Mimomys hordijki s. nov. from the Zuurland borehole (the Netherlands). Mededelingen Nederlands Instituut voor Toegepaste Geowetenschappen TNO 60: 187-192.

Vonhof, H.B., Wesselingh, F.P. \& Ganssen, G.M., 1998. Reconstruction of the Miocene Western Amazonian aquatic system using molluscan isotopic signatures. Palaeoecology, Palaeoclimatology, Palaeogeography 141: 85-93. 